\title{
Diversity and Distribution of Polychaetes Associated with Macroalgae along the Alexandria Coast, Egypt
}

\author{
Rasha Hamdy, Abd El-Ghany N. Khalil, Manal M. Atta and Heba G. Ibrahim
}

Department of Oceanography, Faculty of Science, Alexandria University, Alexandria, POB: 21511, Egypt

rasha_hamdy555@yahoo.com

\begin{abstract}
The relationship between benthic macroalgae and associated polychaetes was studied monthly from October 2014 to October 2015 along the Alexandria coast, Egypt. A total of 56 polychaete species were found among 28 macroalgal species, which belonging to green, brown and red algae. The red algae hosted pronouncedly higher number of polychaete species than the brown and green algae, particularly during winter and spring, while green algae were associated with higher number of polychaete species in January, April, August and October 2015. In contrast, the average count of polychaete individuals associated with the green algae was higher in winter and autumn than that recorded with the red algae, while low with both red and green algae in spring and summer, and very poor within the brown algae. The present study revealed that the structure of algal species my affect the diversity and abundance of the associated polychaetes and the diversity of these worms varied among the hosting algal species.
\end{abstract}

Keywords: Egyptian coast, Benthic fauna, Macroalgae, Red algae, Green algae, Annelida.

\section{Introduction}

The coastal benthic habitats are the most productive areas in the marine ecosystems, because of the great amount of nutrients received from the terrestrial system causing the increase of macroalgal biomass (Kelaher and Castilha, 2005). Macroalgal communities of coastal ecosystems play a key role in maintaining overall coastal biodiversity ( $\mathrm{Ba}-$ Akdah et al., 2016) as different marine invertebrates are frequently associated with them, such as polychaetes, amphipods, isopods, gastropods and mussels (Christie et al., 1998; Sanchez-Moyano et al., 2007; Cunha et al., 2013). Macroalgae provides significant feeding, shelter, refuge, and nursery ground for numerous animal assemblages in the coastal zone, and can affect their distribution and abundance (Gil et al., 2006; Bracken et al., 2007). In addition, coastal macroalgae can protect the benthic organisms from wave action, heat and desiccation (Moore, 1978; Hicks, 1980). The structure of the macroalgal thallus provides different habitat complexity that enhances diverse macrofaunal assemblages (Jeffries, 1997). Algal coverage enhances habitat variation, supporting a higher number of polychaete species than less complex habitats (Abbiati et al., 1987; Giangrande, 1988). For example, Jania rubens coverage was among the variables affecting the distribution of hard bottom assemblage, and might represent a suitable habitat for polychaetes due to its structural complexity (Dorgham et al., 2014). Similarly, the calcified complex algae are 
suitable as polychaete habitats (Tena et al., 2000). However, other algae with less complex thalli (i.e. Enteromorpha sp., Petalonia sp., Ulva rigida, Colpomenia sinuosa) contributed significantly to explain the variation of Alexandria hard bottom polychaete assemblages, as observed elsewhere (Musco, 2012). Furthermore, variation in the distributions of some crustaceans were positively related to variations in the cover of some dominant algal species, while no relation was observed with the animal components of fouling communities (Hamdy et al., 2018).

Polychaetes are the most diverse and abundant benthic communities and are considered good indicator of species richness of benthic invertebrate assemblages (Van Hoey et al., 2004). Polychaetes represent an essential component of the marine benthic fauna, with pronouncedly high biodiversity as well as numerical density (Fauchald, 1977). They are important diet for many marine fishes and invertebrates (Gambi and Giangrande, 1986), in commercial uses (Gambi et al., 1994) and in aquaculture (Pausoao et al., 1995). Further, polychaete community are used in assessing the environmental health (Gopalakrishnar and Nair, 1998; Sarkar et al., 1999) and in biological criteria for the water quality (Lardicci et al., 1997; Giangrande and Fraschetti, 1996; Samuelson, 2001), as they act as good bioindicators of environmental conditions, particularly of organic matter in the sediments (Méndez et al., 1998; Simboura and Nicolaidou, 2001).

Numerous studies have been done on the polychaete community in the Egyptian Mediterranean coast, with high stress on the Alexandria coast, the majority of these studies were carried out during the past two decades (Selim, 1996 a,b,c; Abd El-Naby, 1999; 2005; Selim et al., 2006a,b, Dorgham et al., 2013; 2014; Dorgham and Hamdy, 2015). However, the majority of these studies were concentrated on the species composition and abundance of polychaetes either along the Alexandria coast or in the Eastern Harbour, while some of them recorded new coming species to the area.

The present study aims to follow up the relationship between the macroalgal cover and the composition and abundance of the associated polychaetes on hard bottoms along the Alexandria coast.

\section{Materials and Methods}

\subsection{Study Area}

The coast of Alexandria extends about $35 \mathrm{~km}$ along the Egyptian Mediterranean coast. It is mostly sandy, with some natural rocky areas and intensive shore armoring structures, extending both along the shore and inside the sea.

The present study was carried out at four sites, representing different habitats of the study area (Fig. 1).

1. Abu Qir (AQ) $\left(31^{\circ} 20^{\prime} 16.80^{\prime \prime} \mathrm{N}\right.$ $\left.30^{\circ} 04^{\prime} 52.12^{\prime \prime} \mathrm{E}\right)$ is an exposed area lying east of Alexandria City with sandy bottom alternating with large natural rocky patches.

2. Gleem (GL) $\left(31^{\circ} 14^{\prime} 30.68^{\prime \prime} \mathrm{N}\right.$ 29०57'38.98"E): Rocky sheltered area protected by concrete blocks, has small pieces of natural rocks.

3. El Kashafa (EK) $\left(31^{\circ} 12^{\prime} 62.74^{\prime \prime} \mathrm{N}\right.$ 29०54'23.91"E): Sheltered area inside the Eastern Harbour, with concrete blocks.

4. El-Mex (MX) $\left(31^{\circ} 09^{\prime} 14.93^{\prime \prime} \mathrm{N}\right.$ $\left.29^{\circ} 50^{\prime} 52.38^{\prime \prime} \mathrm{E}\right)$ is an exposed rocky area within El-Mex Bay, receiving brackish water effluents of agricultural, industrial, and sewage discharge from the adjacent Lake Mariut. 


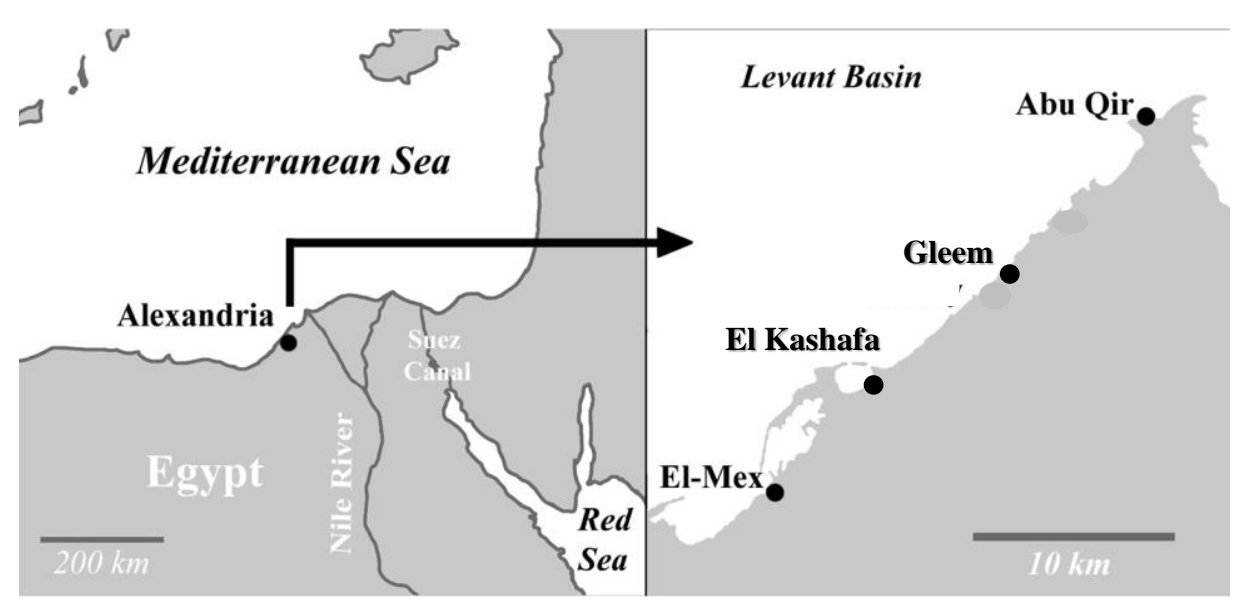

Fig. 1. The coast of Alexandria including the sampling sites (after Dorgham et al., 2014).

\subsection{Sampling}

Macroalgal samples were collected on monthly basis from October 2014 to October 2015 from the selected sites. Water samples were also collected for the analysis of physico-chemical parameters. Water temperature was measured in situ, using a simple thermometer, graduated to $100^{\circ} \mathrm{C}$; salinity was determined by a calibrated Beckman Induction Salinometer (Model RS7C), and $\mathrm{pH}$ was measured in situ by digital portable $\mathrm{pH}$-meter (Cyberscan $10 \mathrm{pH} ; \mathrm{pH}-{ }^{\circ} \mathrm{C}$ Meter). Dissolved oxygen (DO) was determined according to the method described by Strickland and Parsons (1972). Nitrate and phosphate were determined following Moorcroft et al., (2001) using spectrophotometer (HACH-DRL 2000).

Biological samples were collected in three replicates within the depth range of $0.5 \mathrm{~m}$ by removing the macroalgae and the associated fauna by careful scraping the hard substrates within a metallic quadrat of $25 \times 40$ $\mathrm{cm}$ and the collected samples were fixed in $4 \%$ neutralized formalin. In the laboratory, the collected macroalgae were placed in big plastic container, washed carefully to free the attached polychaetes, which were then isolated in plastic jars and finally preserved in $70 \%$ ethanol. Polychaete identification was done according to Fauvel (1923, 1927), Fauchald (1977) and San Martin (1984, 2003). The wet weight of the algae was taken after removing any visible sessile invertebrates or other epiphytes, and the algal species were identified to species level, following Taylor (1945), Nasr and Aleem (1949), Duerden and Jones (1981), Campbell (1982), El-Zayat (2012) and Diaz-Tapia and Barbara (2014).

\section{Statistical Analysis}

\subsection{Diversity Indices}

The Shannon index was calculated according to the equation of Shannon \& Weaver (1949), Pielou's evenness index was found as a ratio of observed diversity to maximum diversity (Magurran, 2003), and species richness (SR) was determined according to the equation given by Margalef (1958). Dominance (CDI) was calculated using the community dominance index described by Mc-Naughtn (1968).

Variations in species composition and abundance, number of species and diversity were analyzed with PERMANOVA and ANOVA. The model consisted of two orthogonal factors: "algal type" (two levels fixed: green algae, red algae) and "month" (13 levels random). Each term in the 
PERMANOVA and ANOVA was tested using 999 random permutations of the appropriate units.

Non-metric multi-dimensional scaling (nMDS) analysis was performed in order to obtain a graphic visualization of similarities (Bray-Curtis) among polychaete assemblages of the two algal habitats (red and green algae). Environmental variable vectors were over imposed in order to highlight their correlation with the polychaete assemblages of the two different algal types and of the four sampling sites.

SIMPER (Similarity percentage) analysis was performed in order to highlight the species mostly contributing to differentiate the assemblages associated to the two algal habitats analyzed. The analyses were performed using the PRIMER v6 software, including the add-on package PERMANOVA.

\section{Results}

\subsection{Physical Chemical Conditions}

The physical chemical parameters are given in Table 1 indicate that water temperature displayed clear seasonal variation between the winter minimum in February and the summer maximum in $\mathrm{Au}$ gust. Surface salinity varied within a narrow range at most of the sampling sites, except for a wide range at MX due to the huge amount of brackish water discharged from Lake Mariut through El-Umoum Drain. Both pH and dissolved oxygen experienced narrow monthly variations at most sites except at $\mathrm{MX}$, where $\mathrm{pH}$ was relatively low and DO displayed wide variation. Nitrate sustained low concentration over the whole area of study, with the lowest values during spring and summer and comparatively high values during autumn and winter. Phosphate showed little spatial differences most of the year, especially during the period from October to April.

Table 1. Annual average values of the physical chemical parameters at the sampling sites from October 2014 to October 2015.

\begin{tabular}{|c|c|c|c|c|c|c|}
\hline & $\begin{array}{c}\text { Salinity } \\
\mathbf{( \% )}\end{array}$ & $\begin{array}{c}\text { Temp. } \\
\left({ }^{\circ} \mathbf{C}\right)\end{array}$ & $\mathbf{p H}$ & $\begin{array}{c}\text { Dissolved } \\
\text { oxygen } \\
(\mathbf{m g} / \mathbf{l})\end{array}$ & $\begin{array}{c}\text { Nitrate } \\
\text { conc. } \\
(\boldsymbol{\mu M})\end{array}$ & $\begin{array}{c}\text { Phosphate } \\
\text { conc. } \\
(\boldsymbol{\mu M})\end{array}$ \\
\hline & $38.3 \pm$ & $23.61 \pm$ & $7.96 \pm$ & $5.91 \pm$ & $11.54 \pm$ & $0.68 \pm$ \\
AQ & 0.52 & 4.41 & 0.42 & 0.81 & 13.04 & 0.34 \\
\hline & $37.54 \pm$ & $23.76 \pm$ & $7.87 \pm$ & $5.11 \pm$ & $7.22 \pm$ & $0.81 \pm$ \\
GL & 1.20 & 4.30 & 0.31 & 1.14 & 8.05 & 0.20 \\
\hline & $28.07 \pm$ & $23.60 \pm$ & $7.60 \pm$ & $4.57 \pm$ & $9.94 \pm$ & $0.84 \pm$ \\
EK & 2.13 & 4.61 & 0.30 & 1.32 & 6.84 & 0.31 \\
\hline & $10.37 \pm$ & $23.09 \pm$ & $7.45 \pm$ & $2.97 \pm$ & $12.97 \pm$ & $0.84 \pm$ \\
MX & 7.12 & 4.61 & 0.29 & 0.98 & 8.45 & 0.32 \\
\hline
\end{tabular}

\subsection{Macroalgal Community}

A total of 28 macroalgal species were recorded, including 8 species of green algae (Chlorophyceae), 3 species of brown algae (Phaeophyceae) and 17 species of red algae (Rhodophyceae). The majority of the red algae (15 species) were recorded at AQ and the lowest number ( 4 species) at EK, with the dominance of Corallina spp. and Jania spp. The species composition of green algae showed little spatial differences, whereas 6 species existed at AQ against 4-5 species at the other sites, with the dominance of Ulva spp. along the study area. The brown algae were represented by three species only, namely Petalonia fascia, Dictyota dichotoma and Colpomenia sinuosa.

\subsection{Polychaetes}

The polychaete community comprised 56 species, belonging to 44 genera and 19 families. Syllidae (16 species) appeared as the most diverse family, followed by Nereididae (5 species). However, family Serpulidae was represented by the highest number of individuals constituting $72 \%$ of the total polychaetes count, against (14.6\%) for Syllidae and $(9.7 \%)$ for Nereididae. The polychaetes diversity experienced clear spatial differences along the Alexandria coast, where 53 species were recorded at AQ, 
dropped to 41 species at EK (Table 2). In contrast, their numerical abundance demonstrated pronounced variations among the sampling sites, attaining the lowest count (annual average: $243 \mathrm{ind} / \mathrm{m}^{2}$ ) at AQ and the highest count (annual average: $3880 \mathrm{ind} / \mathrm{m}^{2}$ ) at EK (Table 2), with the dominance of Spirobranchus triqueter over the whole area.

Table 2. Algal diversity and number of polychaetes species and abundance (Annual average: ind $/ \mathrm{m}^{2}$ ) among the algal groups at different stations.

\begin{tabular}{|c|c|c|c|}
\hline \multirow[b]{2}{*}{$\begin{array}{l}\text { Type of algal } \\
\text { group }\end{array}$} & \multirow{2}{*}{$\begin{array}{c}\text { No. of } \\
\text { algal } \\
\text { species }\end{array}$} & \multicolumn{2}{|c|}{ Polychaetes } \\
\hline & & $\begin{array}{c}\text { No. of } \\
\text { species }\end{array}$ & $\begin{array}{c}\text { abundance } \\
\left(\text { ind } / \mathbf{m}^{2}\right)\end{array}$ \\
\hline \multicolumn{4}{|l|}{ AQ } \\
\hline Green Algae & 6 & 19 & 54 \\
\hline Red Algae & 15 & 34 & 189 \\
\hline Brown Algae & 3 & 0 & 0 \\
\hline Total & 24 & 53 & 243 \\
\hline \multicolumn{4}{|l|}{ GL } \\
\hline Green Algae & 4 & 16 & 400 \\
\hline Red Algae & 9 & 30 & 737 \\
\hline Brown Algae & 1 & 0 & 0 \\
\hline Total & 14 & 46 & 1137 \\
\hline \multicolumn{4}{|l|}{ EK } \\
\hline Green Algae & 5 & 16 & 2693 \\
\hline Red Algae & 5 & 24 & 1186 \\
\hline Brown Algae & 2 & 1 & 1 \\
\hline Total & 12 & 41 & 3880 \\
\hline \multicolumn{4}{|l|}{ MX } \\
\hline Green Algae & 4 & 23 & 1852 \\
\hline Red Algae & 6 & 25 & 528 \\
\hline Brown Algae & 2 & 0 & 0 \\
\hline Total & 12 & 48 & 2380 \\
\hline
\end{tabular}

The present study revealed that the red algae hosted pronouncedly higher number of polychaete species (53) than the green algae (39), while the abundance of polychaetes associated with green algae (annual average $1250 \mathrm{ind} / \mathrm{m}^{2}$ ) was pronouncedly higher than that (annual average $660 \mathrm{ind} / \mathrm{m}^{2}$ ) with the red algae (Fig. 2). The brown algae hosted extremely poor polychaetes as 4 individuals only were found in one sample. Regarding the temporal pattern, the number of polychaete species with the red algae were the highest during winter and spring and deceased during summer, while those with green algae appeared to be the highest in January, April, August and October (Fig. 2). However, the average count of polychaete individuals among the green algal mats was higher in winter and autumn than that in the red algae, but this count was low in spring and summer among both red and green algae (Fig. 2). The Shannon diversity index for polychaetes in the red algae was more than one during most of the study period and less than one in the green algae except August, 2015 (Fig. 2).

The correlations among the green algae biomass was low and negative with the number of species $(r=-0.167)$ and number of individuals $(\mathrm{r}=-0.451)$ but positive with reference to the Shannon diversity $(r=$ 0.282). The correlations among the red algae biomass was low and negative with the number of individuals $(r=-0.089)$ but it was positive when considering the total number of species $(r=0.211)$ and the Shannon diversity $(\mathrm{r}=0.22)$.

The multivariate Analyses (PERMANOVA) of temporal variation of polychaete distribution between the algae (Table 3) revealed significant temporal variation as well as clear differences between the polychaete species associated to the red and the green algae. The nMDS plot (Fig. 3) showed some differences in temporal distribution of polychaete assemblages in the two algal groups, while the nMDS plot (Fig.4) revealed no clear differences among polychaete assemblages from different sites since symbols tend to mix on the plot. However, it is possible to see a tendency of EK, GL and AQ polychaete assemblages to separate from each other, whilst no clear differences can be seen as far as MX is concerned. 
Table 3. PERMANOVAs testing temporal (monthly) differences in polychaete assemblages associated to red and green algae in the study area. Significant $p$ values are given in italics. Test by permutations (999) based on Bray-Curtis similarity. Data fourth-root transformed.

\begin{tabular}{|c|c|c|c|c|c|c|}
\hline & \multicolumn{5}{|c|}{ PERMANOVA table of results } & \multirow[b]{2}{*}{ Uniquepems } \\
\hline & df & SS & MS & Pseudo-F & $\mathbf{P}($ perm $)$ & \\
\hline Algal type & 1 & 15075 & 15075 & 7.6862 & 0.001 & 999 \\
\hline month & 12 & 38489 & 3207.4 & 1.4067 & 0.004 & 996 \\
\hline Algal type $x$ month & 12 & 23515 & 1959.6 & 0.85941 & 0.846 & 998 \\
\hline Res & 76 & 173290 & 2280.2 & & & \\
\hline
\end{tabular}
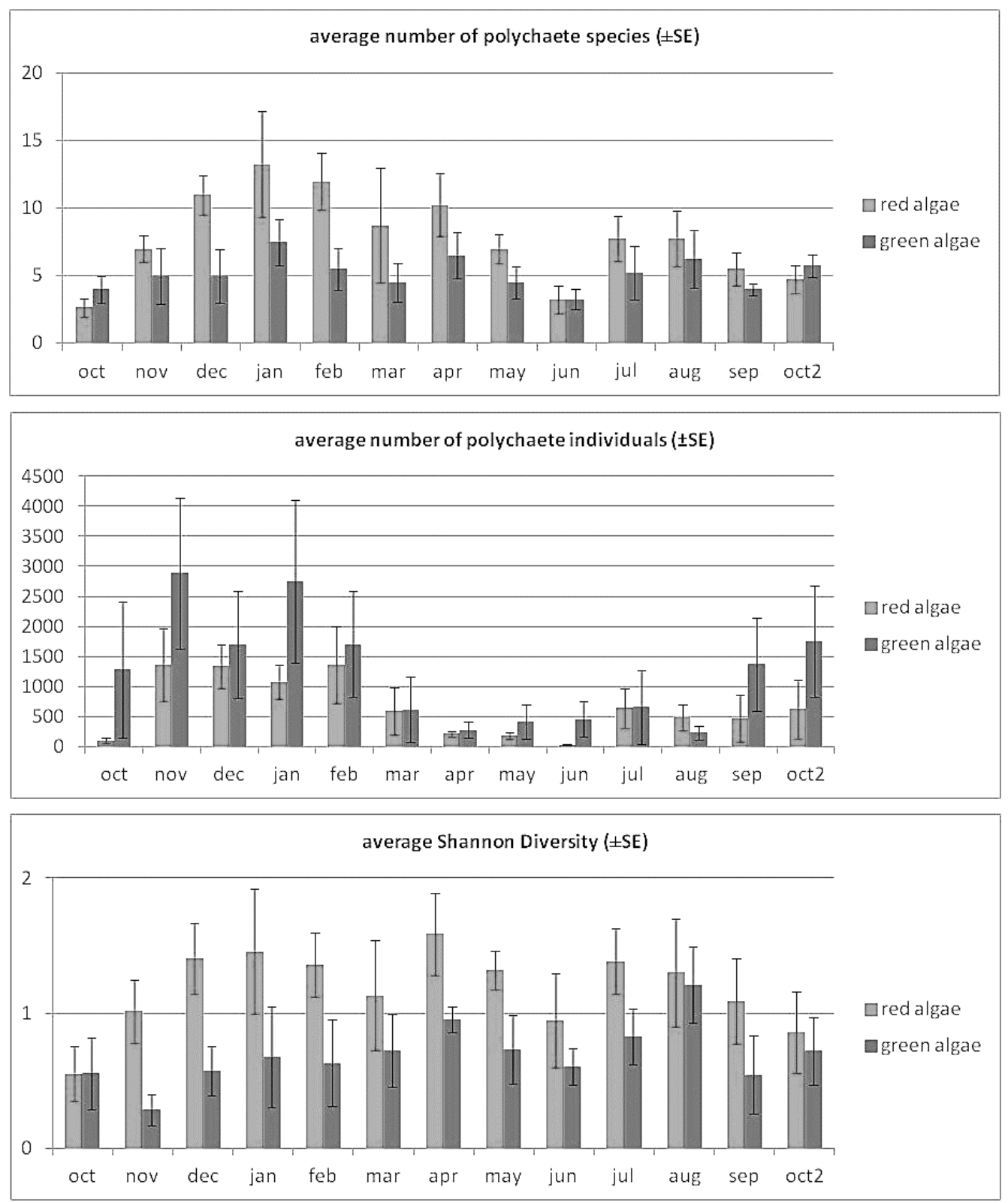

Fig. 2. The monthly average number of polychaete species, individuals and Shannon diversity (the error value indicate SE). 


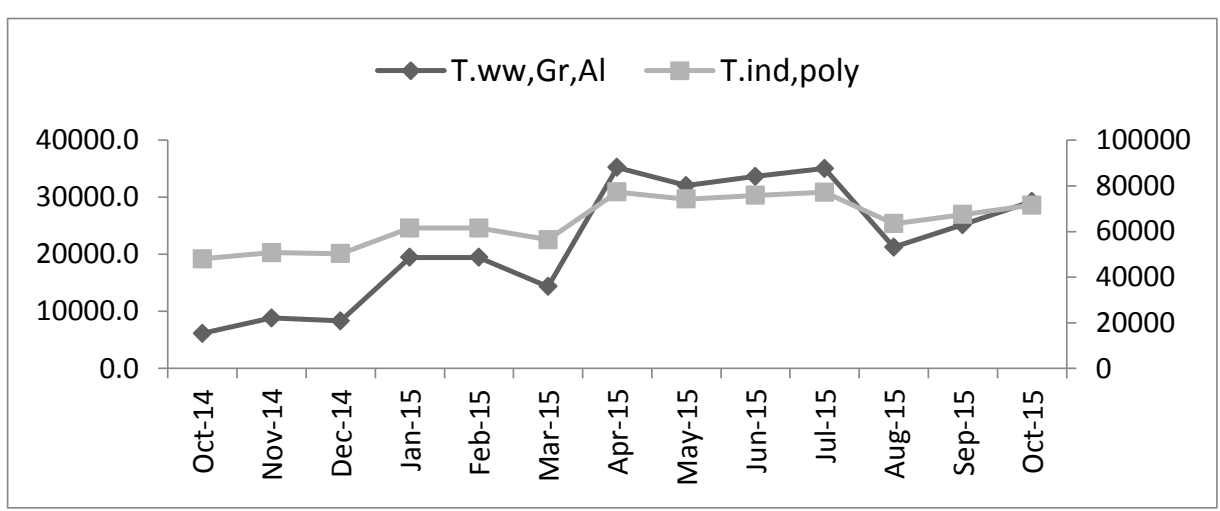

Fig. 3. Monthly relationship between the polychaete abundance and the wet weight of green algae from October 2014 to October 2015.

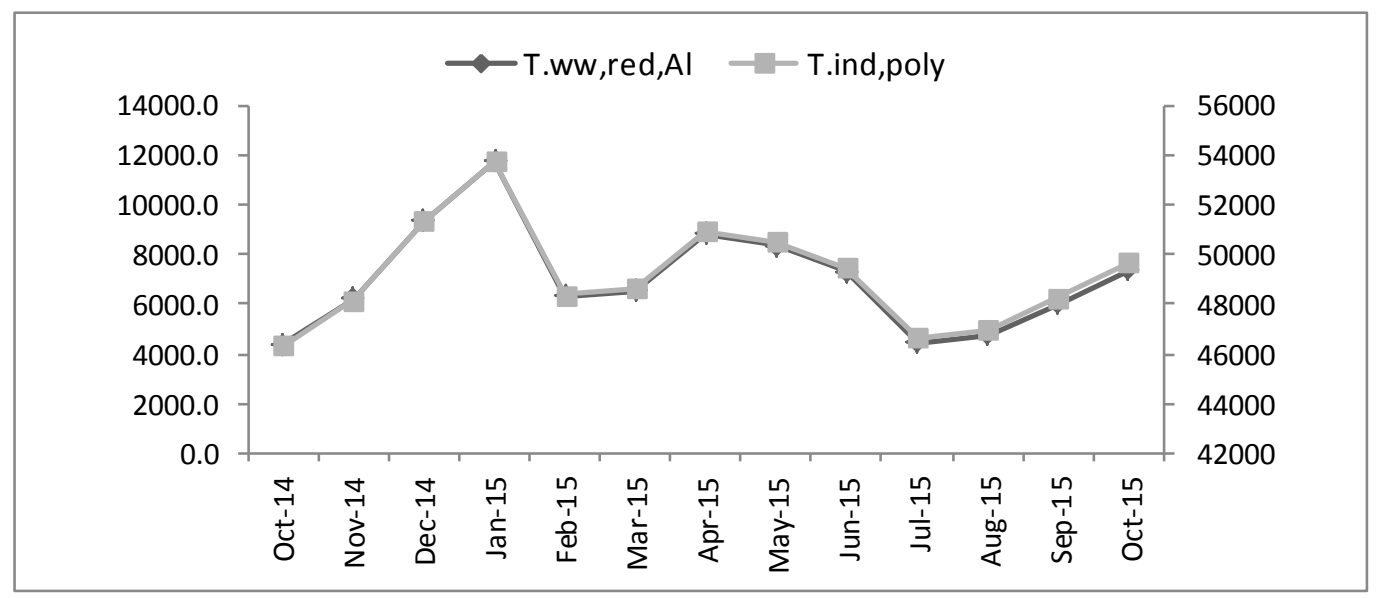

Fig. 4. Monthly relationship between the polychaete abundance and the wet weight of red algae from October 2014 to October 2015.

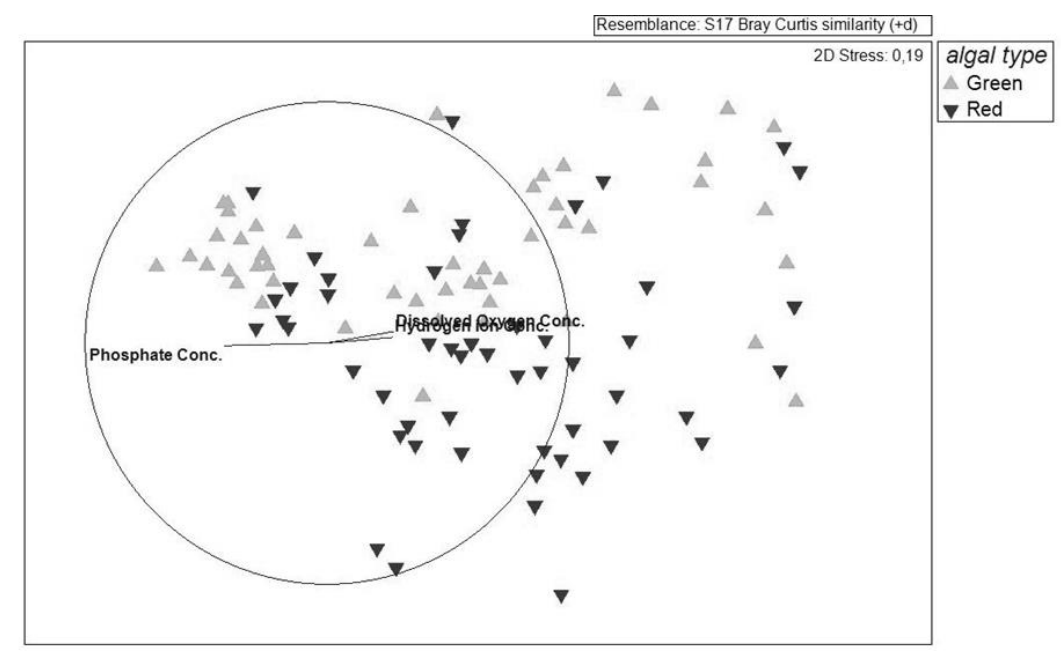

Fig. 5. Non-metric multi-dimensional scaling (nMDS) showing a graphic visualisation of similarities (Bray-Curtis) among polychaete assemblages of the two algal habitats (red and green algae). Environmental variable is over imposed in order to highlight their correlation with the polychaete assemblages. 


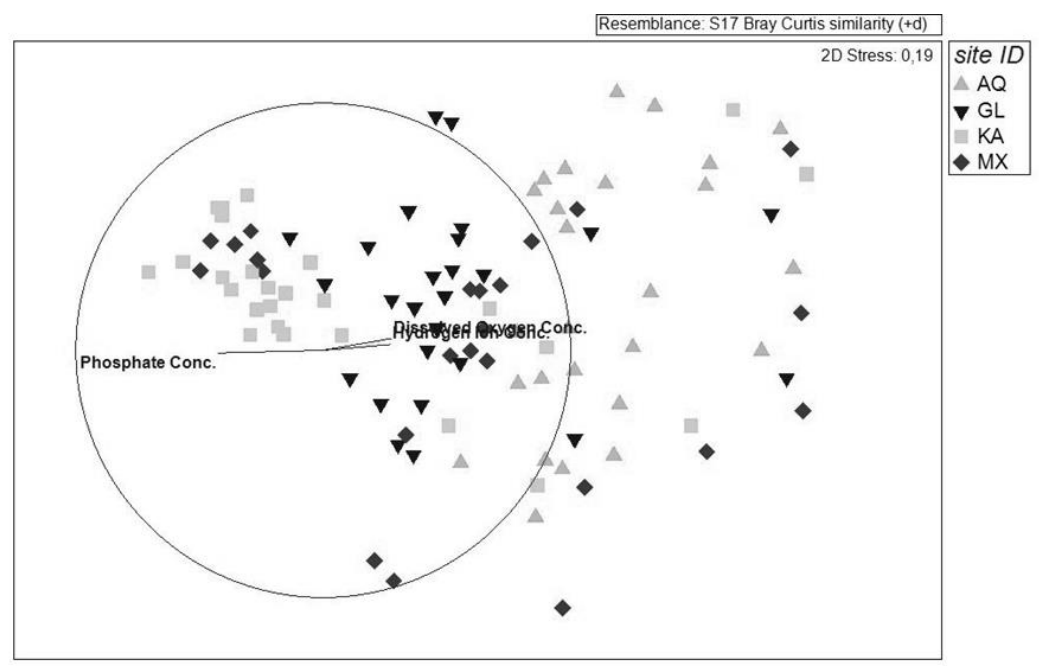

Fig. 6. Non-metric multi-dimensional scaling (nMDS) showing a graphic visualisation of similarities (Bray-Curtis) among polychaete assemblages of the four analyzed sites. Environmental variable is over imposed in order to highlight their correlation with the polychaete assemblages.

\section{Discussion}

It is well known that habitat structure is considered as an important determinant of the diversity and abundance of species present in biological communities (Commito and Rusignuolo, 2000) algae such as calcareous species could have binder and baffler functional role which expand and unite the components of the framework and the settling sediment (Cocito, 2004) since the structure of algae and the leaf surface strongly affects the composition and abundance of the associated fauna (e.g. Bates, 2009; Jones and Thornber, 2010; Cacabelos et al., 2010), and consequently enhance significant correlation between the abundance and diversity of polychaete assemblages with the algal groups (Giangrande et al., 2003). This statements may explain the significant correlation between the number of polychaete species and the red algae and between the polychaete abundance and green algae during the present study. Similar observations were found earlier along the Alexandria coast (Dorgham et al., 2014).
The present study revealed that the several polychaete species preferred red algae as suitable refuge, particularly those of Syllidae, while Nereididae seems to prefer green algae may be due to the algal consumption by these worms (Raffaelli, 2000), while decrease of nereidids diversity among coralline algae is due to the dense accumulation of the epifauna on their thalli that prevents the feeding efficiency of these worms (Menge, 1978). However, Musco (2012) supposed no feeding relationship between polychaetes and macro algae as polychaetes usually feed on detritus.

Our results indicated the occurrence of few specimens of the polychaetes Polyophthalmus pictus and Capitella capitate in association with the green algae Cladophora gracilis, $C$. pellucida, $C$. dalmatica and Enteromorpha intestinalis. Similarly, Bolam and Fernandes (2002) found that Enteromorpha and Cladophora were poor species and dominated by trimmer species such as $C$. capitata and oligochaetes.

The dominance of the red algal species Coralline officinalis, Jania sp., Amphiroa 
compressa, and Amphiroa rigida at $\mathrm{AQ}$ was accompanied by the most diversified polychaete community along the Alexandria coast, particularly the Syllidae and other small size species. Similar observations were reported by Giangrande (1988) who noticed an association between the red algal species, Corallina elongata, Jania rubens, and Laurencia obtusa and the polychaetes of the superficial infralittoral zone such as Platynereis dumerilii, Syllis prolifera, Eunice harassii, Spirobranchus polytrema, Ceratonereis costae, Syllis gracilis, S. prolifera and Nereis zonata, which were also found at AQ. These algal species play significant role in habitat heterogeneity, due to the combination of their rough branched habit and the sessile invertebrates growing directly on the algae (Raffaelli et al., 1999; Nyberg et al., 2009). Furthermore, the calcareous branches of red algae were found to allow the accumulation of sediment and detritus influencing the distribution and composition of associated polychaetes such as Syllid species (Serrano et al., 2006; Tena et al., 2000), and also favoring for the presence of other interstitial species to face both physical stresses (decreasing desiccation and wave force) and biotic stresses (providing refuge from predators and increased niches to reduce competition) (Bradshaw et al., 2003; Quirós-Rodríguez and Campos, 2013). Although Abbiati et al., (1987) and Serrano et al. (2006) stated that the variation in abundance of habitat-forming taxa is one of the most important factors influencing the distribution of Syllidae, Musco and Giangrande (2005) found no significant relationship between red alga and Syllidae distribution.

\section{Conclusion}

The present study indicated that increased biomass of algal cover enhanced the increase polychaete diversity species and consequently other sessile fauna, algal morphology play a significant role in the diversity and abundance of associated polychaete species.

\section{Acknowledgment}

The Authors would like to thank Prof. Dr. M.M. Dorgham, Professor of Biological Oceanography and Marine ecology, Oceanography Department, Faculty of Science, Alexandria University for critical reading and valuable comments on the manuscript. We also thankful to Dr. L. Musco, Laboratorio di Ecologia Marina, 91014 Castellammare del Golfo, Italy, for helping in the statistical analysis of the data.

\section{References}

Abbiati, M., Bianchi, C.N. and Castelli, A. (1987) Polychaete Vertical Zonation Along A Littoral Cliff In The West Mediterranean. P.S.Z.N. Marine Ecology, 8: 33-48.

Abd El-Naby, F. A. (1999) Composition And Distribution of Some Bottom Fauna Associations Along The Alexandria Coast, Mediterranean Sea. M. Sc. Thesis, Faculty of Science, Alex. Univ. 272 p.

Abd El-Naby, F. A. (2005) Systematic And Environmental Studies On Polychaetes From Alexandria Marine Waters. Ph. D. Thesis, Faculty of Science, Alex. Univ., 330 pp .

Aleem, A.A. (1945) Contribution To The Study of The Marine Algae of Alexandria and Its Vicinities. $M$. Sc. Thesis, Farouk University.

Ba-Akdah, M.A., Satheesh, S. and Al-Sofyani, A.A. (2016) Habitat Preference And Seasonal Variability Of Epifaunal Assemblages Associated With Macroalgal Beds On The Central Red Sea Coast, Saudi Arabia. Journal of the Marine Biological Association of the United Kingdom, 96(7): 14571467.

Bates, C. R. (2009) Host Taxonomic Relatedness And Functional-Group Affiliation As Predictors Of Seaweed-Invertebrate Epifaunal Associations. Marine Ecology Progress Series, 387: 125-136.

Bolam, S.G. and Fernandes, T.F. (2002) Dense Aggregations Of Tube-Building Polychaetes: Response To Small-Scale Disturbances. Journal of Experimental Marine Biology and Ecology, 269: 197-222.

Bracken, M., Gonzalez-Dorantes, C. and Stachowicz, J. (2007) Whole-Community Mutualism: Associated Invertebrates Facilitate Dominant Habitat-Forming Seaweed. Ecology, 88(9): 2211-2219. 
Bradshaw, C., Coolins, P. and Brand, A.R. (2003) To What Extent Does Upright Sessile Epifauna Affect Benthic Biodiversity and Community Composition? Marine Biology, 143: 783-791

Cacabelos, E., Olabarria, C., Incera, M. and Troncoso, J. S. (2010) Effects of Habitats Structure and Tidal Height On Epifaunal Assemblages Associated With Macroalgae. Estuarine, Coastal and Shelf Science, 89: 43-52.

Campbell, A. (1982) Flora and Fauna of the Mediterranean Sea. Littlehampton Book Services Ltd; 1st Edition, 320pp.

Christie H., Fredriksen S. and Rind E. (1998) Regrowth Of Kelp And Colonization Of Epiphyte And Fauna Community After Kelp Trawling At The Coast Of Norway. Hydrobiologia, 375/376: 49-58.

Cocito, S. (2004). Bioconstruction And Biodiversity: Their Mutual Influence. Scientia Marina, 68 (Suppl. 1): $137-144$.

Commito, J.A. and Rusignuolo, B.R. (2000) Structural Complexity in Mussel Beds: The Fractal Geometry of Surface Topography. Journal of Experimental Marine Biology and Ecology, 225:133-152. doi: 10.1016/S0022-0981(00)00285-9.

Cunha T.J., Güth A. Z., Bromberg S. and Sumida P.Y.G. (2013) Macrofauna Associated With The Brown Algae Dictyota Spp. (Phaeophyceae, Dictyotaceae) In The Sebastia o Gomes Reef And Abrolhos Archipelago, Bahia, Brazil. Continental Shelf Research, 70: 140-149.

Diaz-Tapia, P. and Barbara, L. (2014) Seaweeds from Sand-Covered Rocks of The Atlantic Iberian Peninsula. Part 2. Palmariales, Ceramiales (Excluding Rhodomelaceae), Gelidiales, Gigartinales, Plocamiales, Rhodymeniales and Scytothamnales. Cryptogamie. Algologie, 35 (2): 157-199.

Dorgham, M. M. and Hamdy, R. (2015) The Role Of Alien Polychaetes Along The Alexandria Coast, Egypt. International Journal of Environmental Research, 9(1): 141-150.

Dorgham, M.M., Hamdy, R., Al-Rashidy, H.H., Atta, M.M. and Musco, L. (2014) Distribution Patterns Of Shallow Water Polychaetes (Annelida) Along The Alexandria Coast, Egypt (Eastern Mediterranean). Mediterranean Marine Science, 15(3): 635-649.

Dorgham, M.M., Hamdy, R., El-Rashidy, H. and Atta, M.M. (2013) First records of polychaetes new to Egyptian Mediterranean waters. Oceanologia, 55(1): 235-267.

Duerden, R. C. and Jones, W. E. (1981) The Host Specificity Of Jania Rubens (L.) Lamour In British
Waters. Proceedings of the International Seaweed Symposium, 8: 313-319.

El-Zayat, F. (2012) Macroalgae And Associated Harmful Microalgae In Different Habitats Along Alexandria Coast. M. Sc. Thesis, Alexandria University.

Fauchald, K. (1977) The Polychaete Worms. Definition and key to the orders, families and genera. Science series. Natural History Museum of Los Angles Country, 282: 118.

Fauvel, P. (1923) Faune de France. Polychaètes Errantes. Le Chevalier, Paris, 488 p.

Fauvel, P. (1927) Rapport Sur Les Annélides Polychètes Errantes. Journal of Zoololgy, 22 (4): 411-439.

Gambi, M.C. and Giangrande, A. (1986) Distribution Of Soft Bottom Polychaetes in Two Coastal Area of The Tyrrhenian Sea (Italy): Structural analysis. Estuarine, Coastal and Shelf Science, 23:847-862.

Gambi, M.C., Castelli, A., Giangrande, A., Lanera, P., Prevedelli, D. and Zunarelli-Vandini, R. (1994) Polychaetes Of Commercial And Applied Interest In Italy: An Over View. In: Proceedings of the 4th Inter. Polychaete Conf., 27 July-1 August 1992, Anger, France, 162: 593-603.

Giangrande, A. (1988) Polychaete Zonation and Its Relation to Algal Distribution Down A Vertical Cliff In The Western Mediterranean (Italy): A Structural Analysis. Journal of Experimental Marine Biology and Ecology, 120: 263-276.

Giangrande, A. and Fraschetti, S. (1996) Effect Of Short-Term Environmental Change On A Brackish Water Polychaete Community P.S.Z.N.I. Marine Ecology, 17(1-3): 321-332 .

Giangrande, A., Delos, A. L., Fraschetti, S., Musco, L., Licciano, M. and Terlizzi, A. (2003) Polychaete Assemblages Along A Rocky Shore On The South Adriatic Coast (Mediterranean Sea): Patterns Of Spatial Distribution. Marine Biology, 143: 11091116.

Gil, L., Louzao, M., David, K., Manuel, A. and Abelló, P. (2006) Oceanographic Habitat Of An Endangered Mediterranean Procellariiform: Implications For Marine Protected Areas. Ecological Society of America, 16 (5): 1683-1695.

Gopalakrishnar, T.C. and Nair, K.K.C. (1998) Subtidal Benthic Macrofauna of the Mangalore Coast, West Coast Of India. Indian Journal of Marine Science, 27: 351-355.

Hamdy, R., Langeneck, J., Atta, M.M., Dorgham, M.M., El-Rashidy, H.H. and Musco, L. (2018) Diversity And Ecology of Crustaceans from Shallow Rocky Habitats Along the Mediterranean Coast of 
Egypt. Marine Biodiversity, DOI 10.1007/s12526017-0787-z.

Hicks, G.R.F. (1980) Structure Of Phytal Harpacticoid Copepod Assemblages And The Influence Of Habitat Complexity And Turbidity. Journal of Experimental Marine Biology and Ecology, 44: 157192.

Jeffries, M. N. J. (1997) Biodiversity and Conservation. London: Routledge. 208pp.

Jones, E. and Thornber, C.S. (2010) Effects of HabitatModifying Invasive Macroalgae On Epiphytic Algal Communities. Marine Ecology Progress Series, 400: $87-100$.

Kelaher, B.P. and Castilla, J.C. (2005) Habitat Characteristics Influence Macrofaunal Communities In Coralline Turf More Than Mesoscale Coastal Upwelling On The Coast Of Northern Chile. Estuarine, Coastal and Shelf Science, 63:155-165.

Lardicci, C., Rossi, F. and Castelli, A. (1997) Analysis Of Macrozoobenthic Community Structure After Severe Dystrophic Crises In A Mediterranean Coastal Lagoon. Marine Pollution Bulletin, 34:536 547 .

Margalef, R. (1958) Information Theory In Ecology. Gen. Syste., 3: 36-71.

Méndez, N., Flos, J. and Romero, J. (1998) Littoral Soft-Bottom Polychaete Communities In A Pollution Gradient In Front Of Barcelona (Western Mediterranean, Spain). Bulletin of Marine Science, 63 (1): 167-178.

Menge, B.A. (1978) Predation Intensity in A Rocky Intertidal Community Relation Between Predator Foraging Activity And Environmental Harshness. Oecologia, 34: 1-16.

Moorcroft, M. J., Devis, J. and Compton, R. G. (2001) Detection \& Determination Of Nitrate And Nitrite: A Review. Talanta, 54(5):785-803.

Moore, P.G. (1978) Turbidity And Kelp Holdfast. Amphipoda. I. Wales and S.W. England. Journal of Experimental Marine Biology and Ecology. 32: 5396.

Musco, L. (2012) Ecology And Diversity Of Mediterranean Hard-Bottom Syllidae (Annelida): A Community-Level Approach. Marine Ecology Progress Series, 461: 107-119.

Musco, L. and Giangrande, A. (2005) A New SpongeAssociated Species, Syllis Mayeri N. Sp. (Polychaeta: Syllidae), With A Discussion On The Status Of S. Armillaris (Müller, 1776). Scientia Marina, 69(4): 467-474.
Nasr, A.H. and Aleem, A. A. (1949) Ecological Studies Of Some Marine Algae From Alexandaria. Hydrobiology, 1: 251-281.

Nyberg C. D., Thomsen, S. and Wallentinus, I. (2009) Flora And Fauna Associated With The Introduced Red Alga Gracilaria Vermiculophylla. European Journal of Phycology, 44(3): 395-403.

Pausoao, P., Machado, M. and Cancelad, F.L. (1995) Marine Pond Culture In Southern Portugal: Present Status And Future Perspectives. Proceedings of the seminar of Ciheam New York on Technology of Aquaculture in the Mediterranean Tecam, Nicosia, Cyprus, 14-17 June. Zaragoza-Spain Ciheam, 16:2130.

Quirós-Rodríguez, J. and Campos, N. H. (2013) Molluscos Asociados A Ensamblajes Macroalgales En El Litoral Rocoso De Córdoba, Caribe Colombiano. Bol. Invest. Mar. Cost, 42 (1): 101120.

Raffaelli, D. (2000) Interactions Between Macro-Algal Mats And Invertebrates In The Ythan Estuary, Aberdeenshire, Scotland. Helgoland Marine Research, 54: 71-79.

Raffaelli, D., Balls, P., Way, S., Patterson, I.J., Hohman, S. and Corp, N. (1999) Major Long-Term Changes In The Ecology Of The Ythan Estuary, Aberdeenshire, Scotland: How Important Are Physical Factors? Aquatic Conservation, 9: 219-236.

Samuelson, G.M. (2001) Polychaetes As Indicators Of Environmental Disturbance On Subarctic Tidal Flats, Iqaliit, Baftin Island, Nunavut Territory. Marine Pollution Bulletin, 42(9): 733-741.

San Martin, G. (2003) A New Species Of Alcyonosyllis Glasby And Watson, 2001 (Polychaeta: Syllidae: Syllinae) From Shimoda, Japan, Commensal With The Gorgonian Melithaea Flabellifera. Zoological Science, 20(3): 371-375.

Sanchez-Moyano, E., Garcia-Asencio, J. and GarciaGomez, J.C. (2007) Effects Of Temporal Variation Of The Seaweed Caulerpa Prolifera Cover On The Associated Crustacean Community. Marine Ecology, 28: 324-337.

Sarkar, S.K., Giri, S., Misra, A., Bhattacharya, B. and Bhattacharya, A. (1999) Intertidal Polychaetes In A Sewage-Fed Tropical Coastal Environment: Assessment Of Impact In Relation To Natural Variability. In: Proceedings of Oceanology international 99 Pacific Rim. Published by Spearhead Exhibition Ltd, Ocean House, 50 Kingston Road, New Malden, Surrey, UK. 85-93 .

Selim, S. A. (1996a) New Records Of Polychaete Annelids From Alexandria Waters. Egypt. Journal of Egyptian-German Society of Zoology, 21(D): 7586. 
Selim, S. A. (1996b) Notes On The Distribution Of Polychaetes Along Alexandria Coast. Egyptian Bulletin of High Institute of Public Health, 26(2): 341-350.

Selim, S. A. (1996c) On some syllid polychaetes from Alexandria waters, Egypt. Journal of EgyptianGerman Society of Zoology, 21(D): 51-73.

Selim, S., Abd El-Naby, F., Gab-Alla, A. F. A. and Gobashy, A. A. (2006a) New Records of Errant Polychaetes from Coastal Waters of Alexandria, Egypt. Egyptian Journal of Aquaculture Research, 32: $210-227$.

Selim, S., Abd El-Naby, F., Gab-Alla, A. F. A. and Gobashy, A. A. (2006b) New Records Of Sedentary Polychaetes From Coastal Waters Of Alexandria, Egypt. Egyptian Journal of Aquaculture Research, 32: $228-241$.

Serrano A., San Martın, G. and López, E. (2006) Ecology of Syllidae (Annelida: Polychaeta) From Shallow Rocky Environments in the Cantabrian Sea (South Bay of Biscay). Scientia Marina, 70s (3): 225-235, http://dx.doi.org/10.3989/scimar. 2006.70s3225.

Shannon, C. E. and Weaver, W. (1949) The Mathematical Theory of Communication: 19-27, 82-
83, 104-107. The University of Illinois. Press. Urbana, IL.

Simboura, N. and Nicolaidou, A. (2001) The Polychaetes (Annelida, Polychaeta) of Greece: Checklist, Distribution and Ecological Characteristics. Monograph of Marine Science, No 4: 115 .

Strickland, J. D. H. and Parsons, T. R. (1972) A Practical Handbook of Sea Water Analysis. Fish. Res. Bd. Canada. Bull. 167, 2nd ed.: 310.

Taylor, W.R. (1945) Pacific Marine Algae of the Allan Hancock Expeditions to the Galapagos Islands. Allan Hancock Pacific Expeditions. 12 (i-iv): 1-528, 3 figs, 100 pls.

Tena, J. M., Azzati, R. C. and Torres, J. (2000) Polychaetes Associated With Different Facies Of The Photophilic Algal Community In The Chafarinas Archipelago. Bulletin of Marine Science, Miami, 67(1): 55-72.

Van Hoey, G., Degraer, S. and Vincx, M. (2004) Macrobenthic Community Structure Of Soft-Bottom Sediments At The Belgian Continental Shelf. Estuarine Coastal and Shelf Science, 59: 599-613. 
تتوع وتوزيع الديدان عديدة الأشواك المصاحبة للطحالب على طول ساحل الأسكندرية،

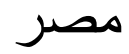

رشا حمدي، و عبد الغتي خليل، و منال عطا، و هبة إبراهيم

قسم علوم البحار، كلية العلوم، جامعة الأسكندربة، الأسكندربية، ص.ب. 101 101 ب، مصر rasha_hamdy555@yahoo.com

المستخلص. تمت دراسة العلاقة بين الطحالب والديدان عديدة الأشواك المصاحبة لها شهريًا

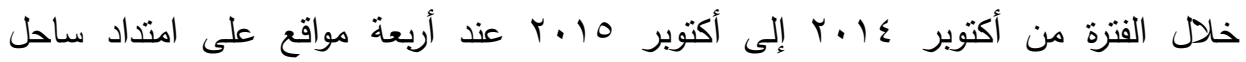

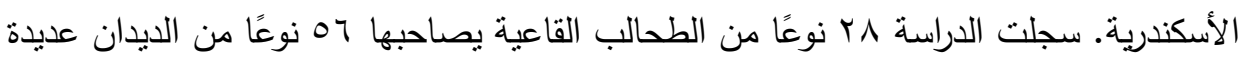
الأشواك. شملت الطحالب سبعة عثر نوعًا من الطحالب الحمراء، ثمانية أنواع من الطحالب الخضراء، وثلاثة أنواع من الطحالب البنية دع تغير واضح في عدد الأنواع عند المواقع المختلفة. استضافت الطحالب الحمراء العدد الأكبر من أنواع الديدان مقارنة بالطحالب الخضراء

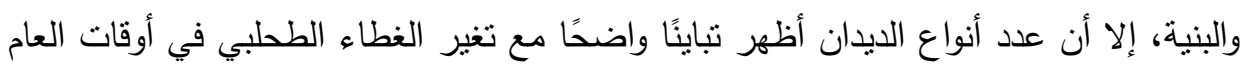
المختلفة، حيث كانت الديدان الأكثر تتوعًا مع الطحالب الحمراء خلال الثتاء والثان والربيع، في حين بدت الديدان أكثر تتوعًا مع الطحالب الخضراء خلال يناير، أبريل، أغسطس، أكتوبر 10 . r. وعلى النقيض سجلت الديدان كثافة عددية أكبر مع الطحالب الخضراء عنها مع الطحالب الحمراء، خاصة خلال فصلي الثتاء والخريف، بينما انخفضت تلك الكثافة مع كل من الطحالب الخضراء والحمراء على السواء خلاه فصلي الربيع والصيف، في حين استضافت الطحالب البنية عددًا قليلا جدًا من الديدان عديدة الأثواك، وقد أوضحت الدراسة الحالية أن تركيب وليب الطحالب يمكن أن يؤثز على تتوع وكثرة الديدان عديدة الأشواك المرتبطة بها وأن تتوع هذه

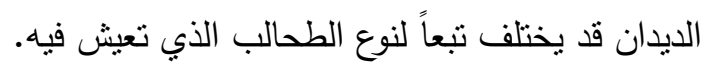
كلمات مفتاحية : الطحالب، الطحالب الحمراء، الطحالب الخضراء، الديدان عديدة الأشواك. 
